\title{
Seasonal Variation in the Plasma Androgens Concentration of Red Deer
}

\author{
ZMIENNOSC SEZONOWA W KONCENTRACJI ANDROGENOW W OSOCZU KRWI \\ JELENIA SZLACHETNEGO
}

\section{Ryszard BARTECKI \& Zbigniew JACZEWSKI}

\begin{abstract}
Bartecki R. \& Jaczewski Z., 1983: Seasonal variation in the plasma androgens concentration of red deer. Acta theriol., 28, 20: 333-336 [With 1 Table \& 1 Fig.]

Plasma androgen concentration was measured in 3 red deer stags by radioimmunoassay monthly during 2 or 3 years. The seasonal changes in androgen concentration were correlated with the reproduction and antler cycles. The highest values from 14 to $36 \mathrm{ng} / \mathrm{ml}$ were found in September and the lowest ones from 0.2 to $1.5 \mathrm{ng} / \mathrm{ml}$ in April and May.

[Institute of Genetics and Animal Breeding, Polish Academy of Sciences, Popielno, 12-222 Wejsuny, Poland]
\end{abstract}

\section{INTRODUCTION}

Plasma androgen concentrations in blood were investigated in the following deer species: reindeer, Rangifer tarandus (Linnaeus, 1758) (Whitehead \& McEwan, 1973; Leader-Williams, 1979); white-tailed deer, Odocoileus virginianus (Zimmermann, 1780) (McMillin et al., 1974; Bubenik et al., 1977; Brown et al., 1978); roe deer, Capreolus capreolus (Linnaeus, 1758) (Barth et al., 1976; Sempéré, 1978; Sempéré et al., 1980; Sempéré \& Boissin, 1981; Sempéré \& Lacroix, 1982); red deer, Cervus elaphus (Linnaeus, 1758) (Lincoln \& Kay, 1979). Lincoln \& Kay have measured fluctuations in the plasma levels of LH and testosterone in 2 intact and 3 castrated red deer males 6 times during the year. The blood samples were collected at 15 -min intervals for $5-7 \mathrm{~h}$ from all the animals. They have found that testosterone concentration in blood fluctuates strongly not only during the season but also during $24 \mathrm{~h}$.

This single work concerning red deer was performed on males from 14 to 27 month old. As it is generally known such young males never take part in reproduction in natural conditions (Jaczewski, 1981). Normally the opportunity to serve hinds starts when stags are at least 4 or 5 years old (Lincoln et al., 1970). In fact the dominant stags are mostly over 6 year old (Bützler, 1974). Therefore the purpose of the present study was to investigate the fluctuations of plasma androgens of red deer stags over 3 years of age.

\section{MATERIALS AND METHODS}

The experiments were performed on 3 stags: No. 1, born May 1976, No. 2, born May 1976 and No. 3, born July 1972. All these stags were taken off their mothers when 3 days old and raised on a cow milk. They became tame during the period of antler growth and very aggressive during the period of hard antlers. The animals were kept in separate pens $25 \times 20 \mathrm{~m}$ on a deer farm, where in neighbouring enclosures about 40 different red deer lived. The stags were fed about 
$1.5 \mathrm{~kg}$ of concentrates per day. From mid-May to mid-October they receive green fodder and during the remainder of the year hay and beetroot. Additionally they received branches of different trees. Experimental stags belonged to the subspecies Cervus elaphus hippelaphus Erxleben, 1777 and weighed over $200 \mathrm{~kg}$ being much larger than the animals used by Lincoln \& Kay (1979), which probably belonged

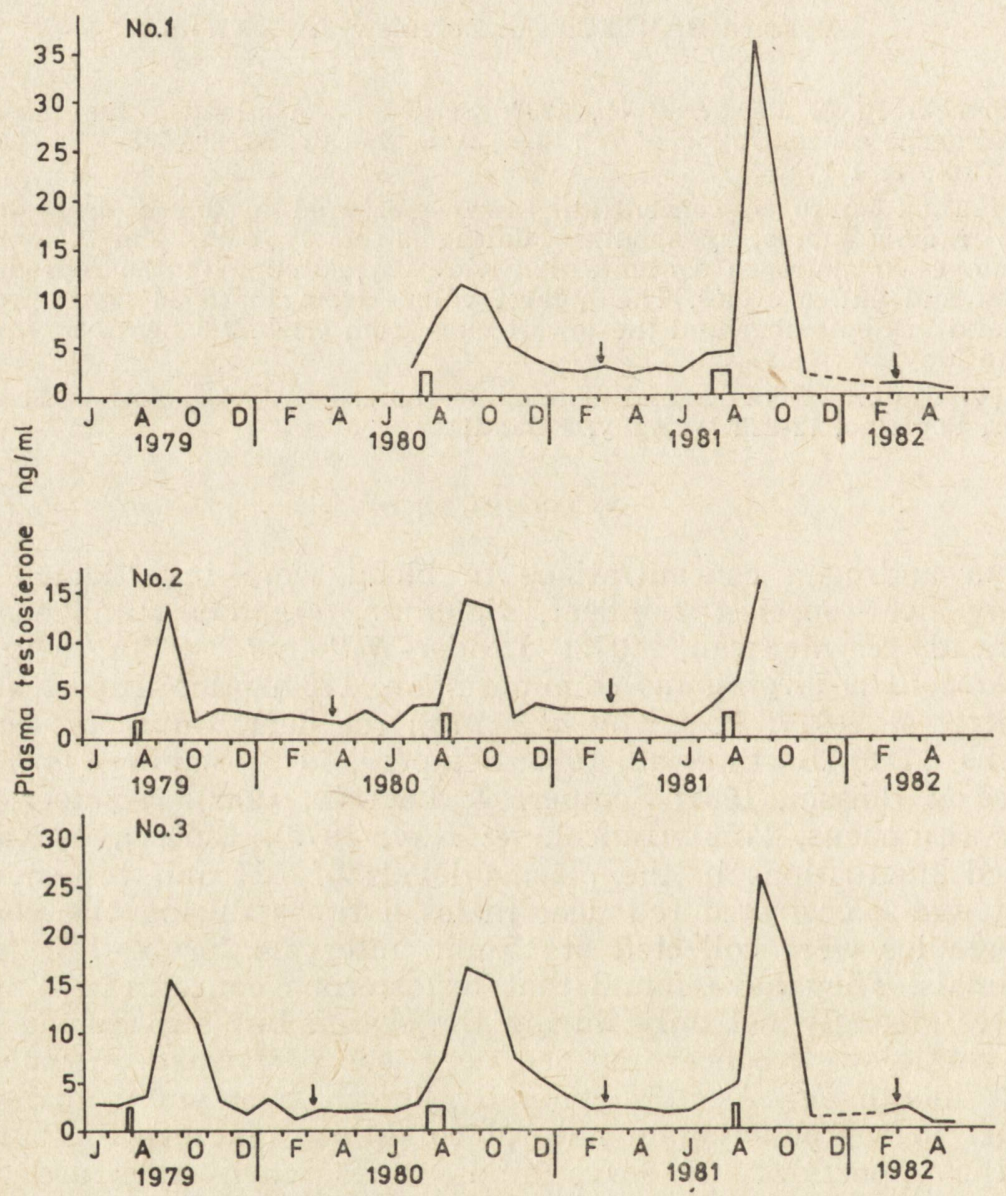

Fig. 1. Fluctuations of plasma androgen concentration in red deer stags. Arrows indicate antler casting. Rectangles indicate the period of velvet shedding. The broken line in December and January of 1982 indicate the lack of data.

to the subspecies Cervus elaphus scoticus Lönnberg, 1906. Owing to their size the manual restraining was rather impossible and the blood collections were always performed after the immobilization with succinylcholine chloride (Suxamethonium chloratum). The blood was collected from the jugular vein centrifuged immediately and the plasma stored at about $-20^{\circ} \mathrm{C}$. Afterwards the frozen samples were transported to the laboratory. The blood samples were collected about 20th each month during the following periods: No. 1 from July 1980 to May 1982, No. 2 from June 1979 to September 1981 and No. 3 from June 1979 to May 1982. In 
December 1981 and January 1982 the plasma samples became accidentaly unfrozen and therefore excluded from the analysis.

Level of plasma androgens was determined by radioimmunoassay $\mathbf{1}^{\mathbf{1}}$ according to method of Kotwica \& Williams (1982) with slight modifications. Plasma duplicates of $0.5 \mathrm{ml}$ were extracted with $6 \mathrm{ml}$ diethyl ether for $30 \mathrm{~min}$ by shaking. After equilibration the water phase of the extract was frozen and an organic phase decanted into the scintillation vials. Than extracts were dried and redissolved in $0.4 \mathrm{ml}$ of ethanol and half of this volume was subjected to RIA. Recovery was estimated by adding approximately $2000 \mathrm{dpm}$ 1,2,6,7-3H-testorone (Radiochemical

Table 1

Antler cycles of the experimental stags.

\begin{tabular}{cll}
\hline Stag number & \multicolumn{1}{c}{ Velvet shedding } & \multicolumn{1}{c}{ Antlers casting } \\
\hline 1 & July 28 - Aug. 4, 1980 & March 3-4, 1981 \\
& July 20-Aug. 12, 1981 & March 2-3, 1982 \\
2 & Aug. 9-11, 1979 & April 4-5, 1980 \\
& Aug. 18-20, 1980 & March 12-13, 1981 \\
& July 30-Aug. 12, 1981 & \\
3 & July 27-Aug. 1, 1979 & March 9, 1980 \\
& July 29-Augu. 18, 1980 & March 2-3, 1981 \\
& Aug. 7-12, 1981 & February 28- March 3, 1982 \\
\hline
\end{tabular}

Centre, Amersham, Great Britain) to $0.5 \mathrm{ml}$ plasma samples and extracted as described above. Recovery averaged $80 \%$. Rabbit antiserum to testosterone were kindly donated by Professor R. Rembiesa (Institute of Pharmacology, Polish Academy of Science, Kraków). Cross-reactivity of this antibody was described by Krzymowski et al., (1981). Sensitivity of method measured according to Abraham (1975) was $15 \mathrm{pg} /$ tube. Linear relationship was shown from the radioimmunoassayable recovery of added amount to testosterone between 25 and $200 \mathrm{pg}$. Organic solvent blanks determined in each assay was negligible.

\section{RESULTS AND DISCUSSION}

As can be seen from Fig. 1 the fluctuations in plasma androgens levels were synchronized with the antler cycle and with the cycle of reproduction.

The results presented above (Fig. 1) indicate that the level of plasma androgens during the rutting season in red deer males increases with age. In our investigations the $24 \mathrm{~h}$ fluctuations were not taken into account and therefore an error is possible depending on the time of $24 \mathrm{~h}$ rhythm of oscillations. However, the androgens levels during the rut were in our investigations much higher than those given by Lincoln \& Kay (1979). They estimated the highest testosterone values in spikers and 2.5 year old males about $13 \mathrm{ng} / \mathrm{ml}$. The oldest of our stags - No. 3 had in every rut the value over $15 \mathrm{ng} / \mathrm{ml}$ and in 1981 the peak was over $25 \mathrm{ng} / \mathrm{ml}$. The maximal value of $36 \mathrm{ng} / \mathrm{ml}$ of androgens

1 Radioimmunoassays of plasma androgens were performed at the Institute of Animal Physiology and Biochemistry of the Academy of Agriculture and Technology at Olsztyn (Head: Professor Tadeusz Krzymowski) by Dr. Jan Kotwica and Regina Nowicka, M. Sc. The authors are greatly indebted for their generous cooperation. 
was estimated in a 5 year old stag - No. 1 in September of 1981 (Table 1). The results presented above are inadequate to estimate the exact relationship between the age and the androgens level. However, it seems that a 5 year old stag achieve a full sexual and endocrinological development. From the deer species hitherto investigated roe and whitetailed deer have during the rut the androgen levels between 3$-12 \mathrm{ng} / \mathrm{ml}$. As high values as red deer were found only in 5-year old reindeer males, which achieved a peak about $35 \mathrm{ng} / \mathrm{ml}$ and in one case $65 \mathrm{ng} / \mathrm{ml}$ (Whitehead \& McEwan, 1973).

The increase of plasma testosterone concentrations during the rut with age was recently also proved on reindeer (Leader-Williams, 1979). The investigations on the regulation of androgens level in red deer are rather scantly and a more exhaustive research seems necessary.

\section{REFERENCES}

Abraham G. A., 1975: Radioimmunoassay of steroids in biological fluids. J. Steroid Biochem., 6: 261-270. - Barth D., Gimenez T., Hoffmann B. \& Karg H., 1976: Testosteronkonzentrationen im peripheren Blut beim Rehbock (Capreolus capreolus L.). Z. Jagdwiss., 22: 134-148. - Brown R. D., Cowan R. L. \& Kavanaugh J. F., 1978: Effect of pinealectomy on seasonal androgen titers, antler growth and feed intake in white-tailed deer. J. Anim. Sci., 47: 435-440. - Bubenik G. A., Bubenik A. B., Brown G. M. \& Wilson D. A., 1977: Sexual stimulation and variations of plasma testosterone in normal, antiandrogen and antiestrogen treated white tailed deer (Odocoileus virginianus) during the annual cycle. Proc. 13th annual meeting of the Congr. Game Biologists, Atlanta. 377-386. Bützler W., 1974: Aggressive and reproductive behaviour, social rank hierarchy and activity rhythms in the red deer (Cervus elaphus L.). Z. Tierpsychol., 16: 1-80. - Jaczewski Z., 1981: Poroże jeleniowatych. Państw. Wyd. Roln. i Leśne: 1-254. Warszawa. Kotwica J. \& Williams G. J., 1982: Relationship of plasma testosterone concentrations to pituitary-ovarian hormone secretion during the bovine estrous cycle and the effects of testosterone propionate administered during luteal regression. Biol. Reprod. - Krzymowski T., Kotwica J. \& Stefańczyk S., 1981: Venous-arterial counter - current transfer of $\left({ }^{3} \mathrm{H}\right)$ testosterone in the vascular pedicle of the sow ovary. J. Reprod. Fert., 61: 317-323. - Leader-Williams N., 1979: Age-related changes in the testicular and antler cycles of reindeer, Rangifer tarandus. J. Reprod. Fert., 57: 117-126. Lincoln G. A. \& Kay R. N. B., 1979: Effects of season on the secretion of $\mathrm{LH}$ and testosterone in intact and castrated red deer stags (Cervus elaphus). J. Reprod. Fert., 55: 75-80. - Lincoln G. A., Youngson R. W. \& Short R. V., 1970. The social and sexual behaviour of the red deer stag. J. Reprod. Fert., Suppl. 11: 71-103. - McMillin J. M., Seal U. S., Keenlyne K. D., Erickson A. W. \& Jones J. E., 1974: Annual testosterone rhythm in the adult white-tailed deer (Odocoileus virginianus borealis). Endocrinology, 94: 1034-1040. - Sempéré A., 1978: The annual cycle of plasma testosterone and territorial behavior in the roe deer. [In: "Environmental Endocrinology", Eds. I. Assenmacher \& D. Farner]. Springer - Verlag: 73-74. Berlin. - Sempéré A., Garreau J. J. \& Boissin J., 1980: Variations saisonnières de l'activité de marquage territorial et de la testostéronémie chez le Chevreuil mâle adulte (Capreolus capreolus L.). CR Acad. Sci. (Paris), 290: 803-806. - Sampéré A. J. \& Boissin J., 1981: Relationship between antler development and plasma androgen concentrations in adult roe deer. J. Reprod. Fertil., 62: 49-53. - Sampéré A. J. \& Lacroix A., 1982: Temporal and seasonal relationships between LH, testosterone and antlers in fawn and adult male roe deer (Capreolus capreolus L.). Acta Endocrinologica, 99: 295-301. - Whitehead P. E. \& McEwan E. H., 1973: Seasonal variation in the plasma testosterone concentration of reindeer and caribou. Can. J. Zool., 51: 651-658. 